\title{
Exotic species predominates in the urban woody flora of central Chile
}

\section{Las especies exóticas predominan en la flora leñosa urbana de Chile central}

\author{
Ludovica Santilli1, Sergio A. Castro ${ }^{1 *}$, Javier A. Figueroa ${ }^{2 *}$, Nicole Guerrero ${ }^{1}$, Cristian Ray ${ }^{1}$, \\ Mario Romero-Mieres ${ }^{3}$, Gloria Rojas ${ }^{4}$ \& Nicolás LaVANDERo ${ }^{1}$
}

${ }^{1}$ Laboratorio de Ecología y Biodiversidad, Departamento de Biología, Centro para el Desarrollo de la Nanociencia y la Nanotecnología (CEDENNA) 917-0124, Universidad de Santiago de Chile, Avenida Libertador Bernardo O’Higgins 3363, Casilla 40, Correo 33, Santiago, Chile.

${ }^{2}$ Centro de Estudios Arquitectónicos, Urbanísticos y del Paisaje, Facultad de Arquitectura, Urbanismo y Paisaje, Universidad Central de Chile.,Avenida Santa Isabel 1186, Santiago, Chile.

${ }^{3}$ Departamento de Ciencias Ambientales, Universidad Católica de Temuco, Rudecindo Ortega 02950, Temuco, Chile.

${ }^{4}$ Museo Nacional de Historia Natural, Área Botánica, Interior Parque Quinta Normal S/N, Casilla 787, Santiago, Chile.

*sergio.castro@usach.cl; javier.figueroa@ucentral.cl

\begin{abstract}
The expansion of cities promotes the replacement of local biotas with exotic species causing a decrease in global diversity. As urbanization continues to expand, efforts directed towards the conservation within urban landscapes could support regional biodiversity conservation. The biogeographic region of central Chile displays a native flora of global importance because of its high endemism. Up to date, studies analysing the composition of the floras within the cities are scarce. The present study aims at characterizing the compositional and distributional patterns of the ornamental flora of five cities of central Chile (La Serena, Valparaíso, Santiago, Rancagua, and Talca). For this purpose, we sampled several streets and squares recording all woody species. The species were then characterized by their biogeographical origin and incidence. It was recorded 302 species of which approx. 86\% were exotic and 14\% were native, a consistent pattern found in the five cities studied; these results contrast with the European urban flora, where native species can usually overcome $50 \%$ of the plant species. Almost half of the exotic species had their origin in Asia (including Australasia, Temperate, and Tropical Asia), Europe, and North America. Consequently, the representation of the regional flora within the urban context is low for central Chile, with the native species registered, accounting for only $0.81 \%$ of the total species described for the country. Urban habitats could support regional biodiversity conservation, so a shift towards sustainable urban planning could promote local biological conservation.
\end{abstract}

KEYWORDS: Native species, plant conservation, urban flora, urban trees.

\section{RESUMEN}

La expansión de las ciudades promueve el reemplazo de biotas locales (nativas) por especies exóticas, lo que causa una disminución en la diversidad. A medida que la urbanización continúa, los esfuerzos dirigidos a la conservación dentro de los paisajes urbanos podrían apoyar la conservación de la biodiversidad regional. La región biogeográfica de Chile Central muestra una flora nativa de importancia mundial debido a su alto endemismo. No obstante, hasta la fecha hay pocos estudios que analicen la composición de las floras dentro de las ciudades de esta región. El presente estudio analiza la composición de la flora ornamental para cinco ciudades de Chile central: La Serena, Valparaíso, Santiago, Rancagua y Talca. Para ello realizamos un muestreo de calles y plazas de estas ciudades, registrando especies de plantas leñosas, distinguiendo su origen biogeográfico y su incidencia. Se registraron 302 especies de las cuales aprox. el 86\% fueron especies exóticas y el 14\% nativas, patrón numéricamente consistente en las cinco ciudades estudiadas. Casi la mitad de las especies exóticas provienen de Asia (incluyendo Australasia y Asia tropical y templada), Norteamérica y Europa. En consecuencia, la representación de la flora regional dentro del contexto urbano es baja para el centro de Chile. Los habitats urbanos podrían apoyar la conservación de la biodiversidad regional, por lo que un cambio hacia una planificación urbana sostenible podría promover la conservación biológica local.

Palabras clave: Árboles urbanos, conservación, especie exótica, especie nativa, flora urbana. 


\section{INTRODUCTION}

Urbanization represents one of the major processes which have had profound effects on biodiversity and its distribution at a global scale (Aronson 2014). The need to maintain the urban habitat in a homeostatic condition, directly affects the habitat and the conservation of the regional biota (McKinney 2006). Considering that recent sources (ONU 2014) estimate a continuing population growth and urbanization across the globe, the threats to biodiversity are likely to increase. Although cities currently represent about $3 \%$ of the world's land usage, their effects on biodiversity extend far beyond their municipal borders (Grimm et al. 2008). The regions with the highest percentages of people living in urbanized areas are Europe, Latin America and the Caribbean, and Northern America with 73\%, 80\% and $82 \%$ respectively. Chile is the third most urbanized country $(89 \%)$ in South America, only preceded by Argentina (92\%) and Uruguay (95\%) (ONU 2014).

As urbanization continues to expand, with obvious consequences on abundance and species richness, efforts directed towards the conservation within urban landscapes could support regional and global biodiversity conservation, restoration and education as well as improve human wellbeing (Dearborn \& Kark 2010, Faeth et al. 2011). The expansion of cities not only alter the habitat of native species but also generates habitat for exotic species that are adapted to urban conditions (McKinney 2006), promoting the replacement of local biotas with cosmopolitan species in a process known as biotic homogenization (McKinney \& Lockwood 1999, Sax \& Gaines 2003). Furthermore, the introduction of exotic species has the potential to cause biological invasions (Richardson et al. 2000), making urban areas pools of potentially spreading taxa. Hence, the balance between native and exotic species could be considered as a first indicator of the effects of urbanization on biodiversity.

So far, relatively few cities have been studied in terms of plant species composition with the majority of them being in Europe (e.g. Grapow et al. 1996, 2006, Kent et al. 1999, Maurer et al. 2000, Leporatti et al. 2001, Van der Veken et al. 2004, Altay et al. 2010, Carretero 2010, Ricotta et al. 2010, Milovic \& Mitic 2012, Stešević et al. 2014). In these analyses, emerges that the native species fraction is commonly higher than the exotic one. Two studies encompassing a total of 117 European and 25 non-European cities have shown that $<50 \%$ of the urban flora were native species (Lososova et al. 2012, La Sorte et al. 2014). Yet, the knowledge about urban biodiversity is considerably inferior in other continents. As for South-America, the attempts to describe urban floras are localized and incipient (Pauchard et al.2006). However, they show a variable representation of native species ranging between 19 and $31 \%$, whereas exotic species ranging between 69 and 81\% (see Méndez 2005, Córdova 2013, Moro \& Castro 2015). Not surprisingly, given the lack of information, these cities have not been included in such large-scale studies as the aforementioned ones. These floristic studies on South American cities show that the number of exotic species is higher than the number of native species. Nevertheless, a generalization on the base of these results is difficult because the sampling was not systematic, and it would be premature to affirm whether the greater number of exotic species reflects a general trend contrasting the one of European cities.

The biogeographic region of central Chile $\left(30-36^{\circ} \mathrm{S}\right)$, displays a native flora of global importance because of its high endemism (45.8\% according to Marticorena 1990). The region mainly encompasses the Mediterranean-type climate flora of Chile and comprises $70 \%$ of the cities of the country, and $62 \%$ of the population (INE 2005). Although the human impact on the vegetation structure of the extraurban landscape has been investigated (Fuentes et al. 1989, Figueroa et al. 2011), studies analysing the composition of the floras within the cities are currently scarce. Particularly in central Chile, studies on urban flora have been carried out only in Santiago (Figueroa et al. 2016, 2018, Fischer et al. 2016, Hernández \& Villaseñor 2018), Temuco (Romero-Mieres et al. 2009), and Curicó (Lozano-Diéguez $\&$ Teillier 2014). Although these studies have analysed different floristic components (i.e. trees, shrubs, and/or herbs; planted or spontaneous species) and habitats (streets, abandoned sites, public and private parks), they have found that exotism (i.e., the proportion of exotic species respect to the total species) ranges between 73 and $92 \%$. Thus, up to date there are no systematic studies that have described and compared the floristic composition of the cities of central Chile and showed how the native flora of the Mediterranean region is represented within them.

The present study investigates the composition of the ornamental flora of five cities of central Chile: La Serena, Valparaíso, Santiago, Rancagua, and Talca. These cities lie on a latitudinal gradient and represent the main urban centres within their respective administrative regions. We realized a systematic sampling of streets and squares aimed at describing and comparing the composition of planted woody species (trees and shrubs). Because of their representation and ornamental importance, we also included palms and bamboos species as well as semi-woody shrubs and succulent. Two main questions leaded our investigation: What is the proportion of native and exotic species in these cities? And does this proportion differs in all the five cities or follows a generalized pattern? Considering the latitudinal disposition of the cities studied, we expect to find a gradient in the representation of native and exotic species associated with environmental conditions observed along the latitude (i.e. temperature and precipitations, see Luebert \& Pliscoff 2006). Because the richness of naturalized species increases with the latitude in extra-urban habitats (Fuentes et al. 2013), it was hypothesized a similar trend for exotic species 
in cities. Additionally, we characterize the composition of the species found in this sampling describing their biogeographical origin, their incidence and their distribution in streets and squares. With this information, we want to draw attention to the scarce representation of the native flora within the cities of central Chile.

\section{METHODS}

\section{STUDY AREAS}

Its was carried out a comprehensive survey of the planted flora of five cities of central Chile: La Serena, Valparaíso, Santiago, Rancagua and Talca (Fig. 1). The area of the cities varies between 46 and $867 \mathrm{~km}^{2}$ with densities ranging between 2,254 and 6,710 inhabitants $\times \mathrm{km}^{-2}$ (INE 2005) (Table 1). La Serena and Valparaíso are coastal cities whereas Santiago, Rancagua and Talca are continental cities (Fig. 1). Santiago is the politic and economic capital of Chile, whilst the other cities represent each the main urban centre (from political, administrative, and economic point of view) of the respective administrative regions (Fig. 1). The foundation of all the cities sampled, date back to the colonial time, more than 300 years ago (Table 1 ).

\section{SAMPLING}

The sampling was carried out between 2012 and 2015. We first generated a specified number of randomly-placed points within the boundaries of each city using ArcGIS (ESRI 2012). Then, the closest street and square to these points were identified using Google Earth. Responding to city size and logistic limitations, the number of points chosen for each city ranged between 64 and 80, except for Santiago whose larger size required a greater sampling effort (Table 1). Sampling along the streets included collecting data from both sidewalks for a length varying between $150 \mathrm{~m}$ and 250 $\mathrm{m}$, while the area of the squares ranged between $13 \mathrm{~m}^{2}$ and $507,000 \mathrm{~m}^{2}$. For all sampling sites, we recorded the presence of all woody planted species, including both trees and shrubs. Furthermore, its was included palms (Arecaceae), bamboos (genera Phyllostachys and Pseudosasa), as well as semi-woody plants (genera Aloysa and Hypericum), cacti (Cactaceae) and succulents (genera Agave, Aloe, and Kalanchoe).

The classification of individual taxa followed Marticorena \& Quezada (1985), Matthei (1995), Rodríguez et al. (1983, 2005), Zuloaga et al. (2009) and Figueroa et al. (2016). Then, nomenclature at species and above species level was updated according to The Plant List (2013). Species were classified as native or exotic to Chile following Marticorena \& Quezada (1985), Matthei (1995), Arroyo et al. (2000), Zuloaga et al. (2009), and Ray et al. (2014). Within the native species, we recognized as 'extralimital native' (see La Sorte et al. 2014) those species native to Chile (see Fig. 1) but not to the regions where the cities object of this study are found; nevertheless in this analyses these species were treated as native. As for the exotic species, their original distribution was determined using the World Geographical Scheme for Recording Plant Distributions (WGSRPD) developed by the Taxonomic Database Working Group (TDWG) (Hollis \& Brummitt 2001). Most of the species showed a wide geographical distribution combining different regions, which were considered as different categories.

\section{AnALYses}

Its was calculated the overall representation of exotic and native species (total pool of species) and compared this result with the proportion of exotic and native species found in each city to assess for statistical difference among cities. To statistically assess the significance of the differences, we used the Pearson's chi-squared, where the observed frequencies in each city were compared with the expected frequencies generated from the total pool of species. By similar procedure, its was also compared the origin of the taxa between different habitat types (streets and squares). Furthermore, its was evaluated whether there was an overall significant difference in the origin of the species and whether the origins of the species were the same among cities.

TABLE 1. The five cities of central Chile object of this study with information about foundation year, area, density and number of plots sampled. / Cinco ciudades estudiadas con información acerca de año de fundación, área, densidad de habitantes y número total de plots empleados en el muestreo.

\begin{tabular}{lcccc}
\hline City & Foundation Year & Area $\left(\mathrm{km}^{2}\right)$ & Density $\left(\right.$ inhabitants $\left.\times \mathrm{km}^{-2}\right)$ & Number OF PLOTS \\
\hline Santiago & 1541 & 867 & 6710 & 468 \\
Talca & 1692 & 46 & 4116 & 78 \\
Valparaíso & 1544 & 47 & 5567 & 64 \\
Rancagua & 1743 & 50 & 4110 & 80 \\
La Serena & 1544 & 65 & 2254 & 80 \\
\hline
\end{tabular}




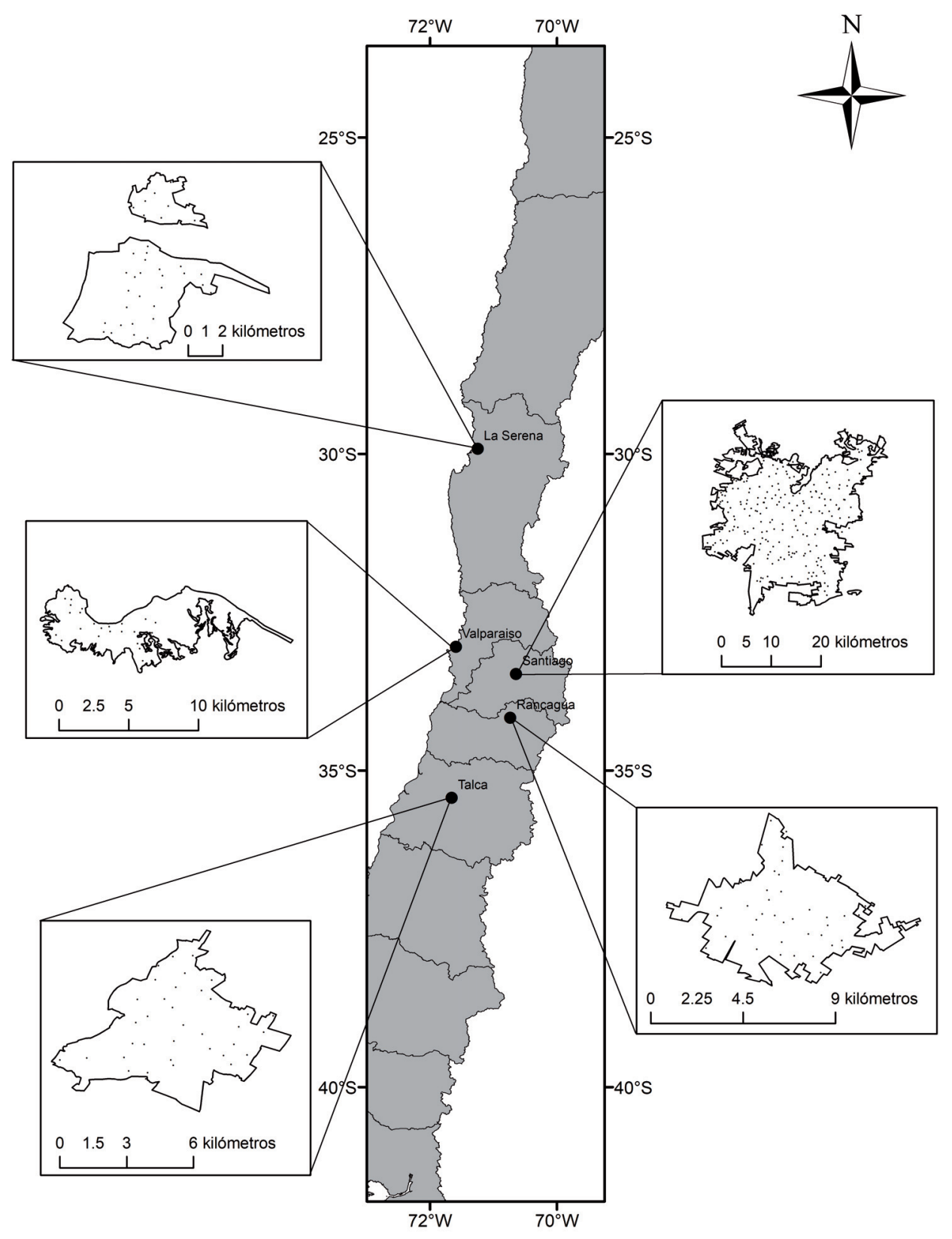

Figure 1. Political map of Chile showing regional division, and close up to the area of central Chile including the cities sampled in this study. / Mapa político de Chile mostrando la división regional administrativa y la ubicación de las cinco ciudades estudiadas.

Additionally, we wanted to assess the incidence of the native and exotic species in the studied cities. We calculated incidence as the number of plots in which the species occurred divided by the total number of plots. This was studied as a function of their biogeographical origin, i.e. native and exotic species. A Kolmogorov-Smirnov test was performed in order to assess the significance of the differences in the incidence between native and exotic species.

\section{RESULTS}

A total of 302 species were recorded for the five cities (Annex 1); among these, $275(91.1 \%)$ species were angiosperms and only 27 (8.9\%) were gymnosperms (Annex 1). Among the angiosperms, we found 71 families and 177 genera (Annex 1). The most represented families in terms of number of species were Rosaceae ( 35 species) and Fabaceae (30 species), followed by Malvaceae and 
Oleaceae (10 species each). The rest of the families included between 1 and 9 species (Annex 1). At generic level, Prunus (12 species) and Acacia (9 species) were the most diverse (Annex 1). The rest of the genera were represented by less than 6 species. As for gymnosperms, we recorded 6 families (Annex 1); Cupressaceae (11 species), Pinaceae (9 species) and Araucariaceae (4 species) were the most diverse families (Annex 1). At generic level, 16 genera were recorded among the gymnosperms, and Cupressus and Araucaria were the most represented, with 4 species each (Annex 1).

Of the 302 species found in this study, its was recorded
$42(13.9 \%)$ native and $260(86.1 \%)$ exotic species (Table $2)$. These frequencies differ of an equitable distribution (50 and 50\%; $\chi^{2}=157$; f.d. $=1 ; \mathrm{P}<0.01$ ), and show that each city had a similar proportion of exotic and native species with no significant difference (Table 2). Similar results were obtained when comparing streets and squares: systematically a higher richness of exotic than native plant, following proportions as $88.6 \%$ and $11.3 \%$ for exotic and native species in streets, and $85.3 \%$ and $14.7 \%$ for exotic and native species in squares (Table 3 ).

TABLE 2. Numbers of exotic and native species found and results from Pearson's chi-squared test comparing the observed frequencies of native and exotic species of the cities to the expected frequencies from the Total pool species. / Número total de especies nativas y exóticas registradas en el muestreo de cinco ciudades y los resultados de la prueba chi-cuadrado de Pearson establecidos al comparar las frecuencias de nativas y exóticas de cada ciudad respecto de la frecuencia esperada a partir del pool de especies totales.

\begin{tabular}{lcccccc}
\hline City & Natives & Exотісs & Total & $\chi^{2}$ & f.d. & P \\
\hline La Serena & 16 & 106 & 122 & 0.06 & 1 & $>0.05$ \\
Valparaíso & 9 & 89 & 98 & 1.82 & 1 & $>0.05$ \\
Santiago & 38 & 242 & 280 & 0.02 & 1 & $>0.05$ \\
Rancagua & 9 & 98 & 107 & 2.69 & 1 & $>0.05$ \\
Talca & 15 & 110 & 125 & 0.37 & 1 & $>0.05$ \\
\hline Total pool & 42 & 260 & 302 & & & \\
species & $(13.9 \%)$ & $(86.1 \%)$ & $(100 \%)$ & & & \\
\hline
\end{tabular}

TABLE 3. Distribution of the native and exotic species in streets and squares in each of the studied cities and results from Pearson's chisquared test. This test compares the frequencies observed in each city with the expected one from the total pool of species. / Distribución de especies nativas y exóticas en calles y plazas de las cinco ciudades estudiadas y resultados de la prueba de chicuadrado de Pearson. Esta prueba compara las frecuencias observadas en cada ciudad con la esperada a partir del pool total de especies.

\begin{tabular}{lcccccc}
\hline City & HАвітAт TYPe & Natives & Exoтіcs & $\chi^{2}$ & f.d. & P \\
\hline La Serena & Street & 9 & 68 & 0.31 & 1 & $>0.05$ \\
& Square & 13 & 89 & 0.11 & 1 & $>0.05$ \\
\hline Valparaíso & Street & 1 & 30 & 2.95 & 1 & $>0.05$ \\
& Square & 8 & 79 & 1.61 & 1 & $>0.05$ \\
\hline Santiago & Street & 26 & 197 & 0.94 & 1 & $>0.05$ \\
& Square & 35 & 201 & 0.16 & 1 & $>0.05$ \\
\hline Rancagua & Street & 5 & 61 & 2.20 & 1 & $>0.05$ \\
& Square & 8 & 83 & 1.98 & 1 & $>0.05$ \\
\hline Talca & Street & 7 & 60 & 0.66 & 1 & $>0.05$ \\
& Square & 14 & 101 & 0.28 & 1 & $>0.05$ \\
\hline Total pool species & Street & $27(11.3 \%)$ & $211(88.6 \%)$ & 1.30 & 1 & \\
& Square & $39(14.7 \%)$ & $227(85.3 \%)$ & 0.12 & 1 & \\
\hline
\end{tabular}


TABLE 4. Species frequency according to their geographical origin (Geographical region) in each studied city. At the bottom of the table are results from Pearson's chi square test; here the observed frequencies were compared with expected frequencies, which were obtained from the total pool species. / Número de especies según su región geográfica de origen (Geographical region), presente en cada ciudad estudiada. En la parte inferior de la tabla se encuentran los resultados de la prueba de chi cuadrado de Pearson; aquí las frecuencias observadas se compararon con las frecuencias esperadas, que se obtuvieron a partir del pool total de especies.

\begin{tabular}{lcccccc}
\hline Geographical region & La Serena & Valparaíso & Santiago & Rancagua & Talca & Total \\
\hline Temperate Asia & 20 & 20 & 61 & 30 & 32 & 63 \\
North America & 11 & 13 & 33 & 16 & 17 & 37 \\
Europe, Temperate Asia, Africa & 11 & 13 & 30 & 13 & 12 & 30 \\
Australasia & 20 & 14 & 28 & 9 & 13 & 29 \\
South America & 9 & 7 & 23 & 5 & 7 & 25 \\
Africa & 12 & 3 & 18 & 2 & 4 & 21 \\
Europe, Temperate Asia & 6 & 7 & 18 & 8 & 11 & 18 \\
Europe & 5 & 4 & 8 & 6 & 6 & 11 \\
North America, South America & 4 & 1 & 8 & 3 & 3 & 8 \\
Temperate Asia, Tropical Asia & 3 & 2 & 5 & 2 & 2 & 6 \\
Europe, Africa & 0 & 1 & 3 & 2 & 1 & 3 \\
Temperate Asia, Tropical Asia, Australasia & 2 & 2 & 2 & 1 & 1 & 2 \\
Tropical Asia, Australasia & 1 & 0 & 0 & 0 & 1 & 2 \\
Temperate Asia, Africa & 0 & 0 & 1 & 0 & 0 & 1 \\
Temperate Asia, South America & 1 & 1 & 1 & 0 & 0 & 1 \\
Tropical Asia & 0 & 0 & 1 & 0 & 0 & 1 \\
Australasia, Tropical Asia, Africa & 1 & 1 & 1 & 1 & 0 & 1 \\
Pacific & 0 & 0 & 1 & 0 & 0 & 1 \\
\hline Total pool species & 106 & 89 & 242 & 98 & 110 & 260 \\
$\chi^{2}$ & 0.1 & 5.3 & 0.9 & 9.3 & 6.8 & 7 \\
f.d. & 7 & 7 & 7 & $>0.05$ & \\
P & $>0.05$ & $>0.05$ & $>0.05$ & \\
\hline
\end{tabular}

Of the 42 native species, 6 were extra-limital natives: Araucaria araucana (Molina) K. Koch, Tara spinosa (Molina) Britton \& Rose, Erythrostemon gilliesii (Hook.) D. Klotzsch, Cylindropuntia tunicata (Lehm.) F.M.Knuth, Hebe salicifolia G. Forst., and Schinus areira L. On the other hand, the 260 exotic species recorded fell in 18 biogeographical categories (Table 4); 39.6\% of the exotic species, had their original distribution in different regions of Asia, including Temperate Asia, Tropical Asia and Australasia, with Temperate Asia alone counting for $24.2 \%$ (Table 4). North American species added up 14.2\%, South America account for $9.6 \%$ of the exotic species, while African and European species $8 \%$ and $4.2 \%$ respectively (Table 4). The rest of the taxa showed original distributions which combines different regions and continents (Table 4).
No statistical differences were obtained when comparing the relative proportion of species falling in each category among the five cities (Table 4).

The 302 species recorded, ranged incidence values between 0.001 and 0.430 . In $92.1 \%$ of the cases $(278$ species), incidence was $<0.1$, while the remaining 24 species showed higher values between 0.1 and 0.430 (Fig. 2). The most frequent exotic species were Nerium oleander L., Melia azedarach L., Liquidambar styraciflua L., Ligustrum lucidum W.T. Aiton, Ligustrum ovalifolium Hassk., Prunus cerasifera Erhr., Robinia pseudoacacia L., and Acer negundo L., ranging between 53.9 and 85.8\%; meanwhile, the most widely distributed native species were Cestrum parqui (Lam.) L'Hér., Cryptocarya alba (Mol.) Looser, Acacia caven (Mol.) Mol., Maytenus boaria Mol., Quillaja 
saponaria Molina, and Schinus areira L., ranging between $12.7 \%$ and $54.1 \%$. When comparing incidence values between exotic and native species for each city and for all the cities together, no statistical difference were observed (see Fig. 2). Of the 302 species found in our sampling, 41 species $(13.6 \%)$ were shared by all cities while 119 species (39.4\%) were unique to one city. Of the former, 37 were exotic among which the aforementioned Acer negundo, Robinia pseudoacacia and Prunus cerasifera, and 4 were the native Quillaja saponaria, Acacia caven, Cryptocarya $a l b a$ and Schinus areira. These findings show an ornamental trend that results in a few species widely distributed and many species narrowly distributed.
Exotic
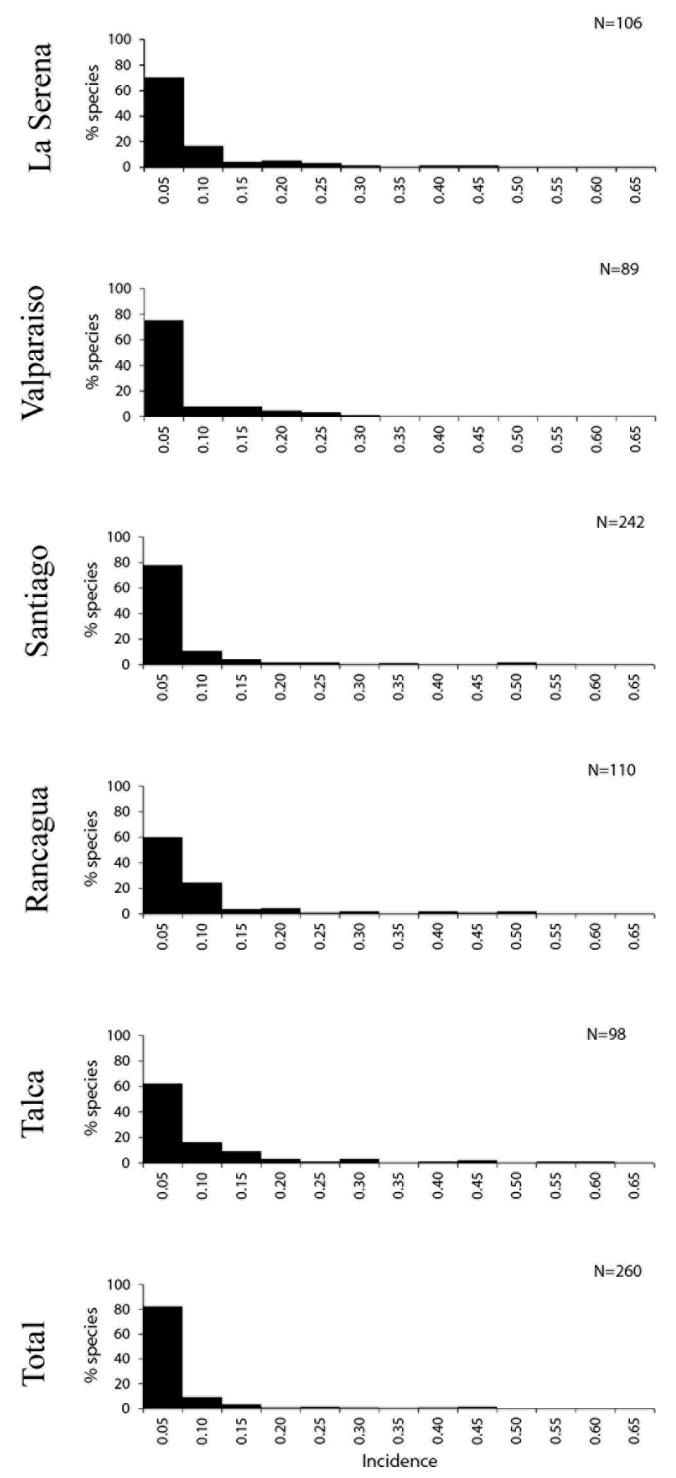

Native
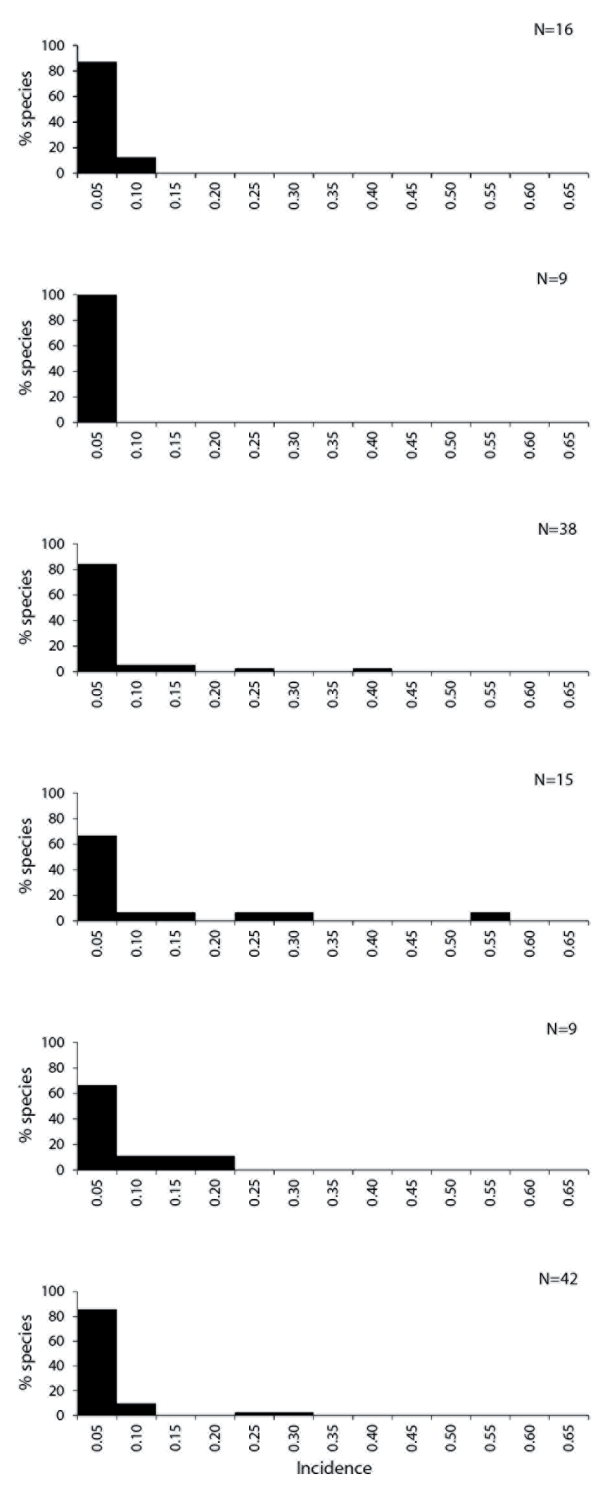

FIGURE 2. Percentage of native and exotic species plotted against their incidence classes, compared among the five cities and overall. All the cities show a similar pattern of species incidence, with a few taxa well represented across the plots of their boundaries and many taxa present in only a few plots (rare species); comparison were performed by a Kolmogorov-Smirnov test $($ La $S e r e n a ~ D=0.1, P=0.925$; Valparaíso $\mathrm{D}=0.2, \mathrm{P}=0.700$; Santiago $\mathrm{D}=0.1 \mathrm{P}=0.304$; Rancagua $\mathrm{D}=0.1, \mathrm{P}=0.294$; Talca $\mathrm{D}=0.1, \mathrm{P}=0.9$; Total $\mathrm{D}=0.1, \mathrm{P}=0.171$ ). / Distribución porcentual de la incidencia de especies exóticas y nativas en cinco ciudades estudiadas. Las distribuciones fueron comparadas usando pruebas de Kolmogorov-Smirnov (La Serena $\mathrm{D}=0.1, \mathrm{P}=0.925$; Valparaíso $\mathrm{D}=0.2, \mathrm{P}=0.700$; Santiago $\mathrm{D}=0.1 \mathrm{P}=0.304$; Rancagua $\mathrm{D}=0.1, \mathrm{P}=0.294$; Talca $\mathrm{D}=0.1, \mathrm{P}=0.9$; Total $\mathrm{D}=0.1, \mathrm{P}=0.171$ ). 


\section{DISCUSSION}

Previous studies on urban floras have shown that cities may support strikingly high biotic diversity (e.g. Godefroid \& Koedam 2007) and possibly represent the regional flora to which the cities belong (e.g. La Sorte et al. 2014). However, our study shows that native species represent approximately $14 \%$ of the urban flora, nearly $25 \%$ of the Chilean native trees $(\approx 120$ species; see Rodríguez et al. 1983$)$ and only $0.81 \%$ of the total species described for Chile $(\approx 5,000$ species; see Marticorena \& Quezada 1985). Thus, the representation of the regional flora within the urban context appears to be low for central Chile. With regards to the exotic flora (which includes naturalized and non-naturalized species), it is difficult to establish quantitative comparisons because the study of their diversity has focused mainly upon the naturalized plants (e.g. Arroyo et al. 2000, Figueroa et al. 2004, Pauchard et al. 2004, Castro et al. 2005, Fuentes et al. 2008). In a floristic guide, Hoffmann (1998) summarized 94 exotic woody species for the total Chilean cities, of which $98 \%$ were found in this study. In a more exhaustive study, Rodríguez et al. (2005) recorded 158 exotic species (trees and arborescent species) for Chile, of which 64\% were found in this study. These values indicate that within Chilean cities, the exotic trees and arborescent species are more diverse (i.e. greater species richness) and better represented with respect to the total floras (native and exotic sets) than the native ones.

These results are in line with the results of other studies carried out on planted and spontaneous flora of other cities of central Chile. Lozano-Diéguez \& Teillier (2014) and Romero-Mieres et al. (2009) found that only $8 \%$ of the ornamental flora of Curicó and $27 \%$ of the ornamental flora of Temuco, respectively, was native. Recently, Hernández \& Villaseñor (2018) reported an increase in the representation of native trees within Santiago over the last 12 years. Nevertheless, Figueroa et al. (2016) highlighted that the composition of the vascular spontaneous flora of Santiago was represented by $15 \%$ of native species and $85 \%$ of exotic species. Fischer et al. (2016) analysed the composition of spontaneous weeds in grassland and wooded areas of 15 parks of Santiago and found that exotic species contributed for $>90 \%$ to the total diversity. Gärtner et al. (2015) conducted a study on the ruderal herbs spontaneously growing in public spaces of Santiago and found that $16 \%$ of the taxa were native while $84 \%$ were exotic; additionally, Figueroa et al. (2018) found that $84 \%$ of the taxa present in private and public parks in Santiago were exotic species. Interestingly, by using a systematic sampling for the five studied cities we recorded 302 species of which approx. $86 \%$ were exotic and $14 \%$ were native; these figures were numerically consistent among the five cities studied not showing evidence of a gradient trend as we initially hypothesized by comparison with naturalized plants in extra-urban habitats (Fuentes et al. 2013). Additionally, the proportion of native and exotic urban flora encountered in central Chile, differ from the European trend where better representation of the regional flora has been found (Aronson et al. 2014, Celesti-Grapow et al. 2013, La Sorte et al. 2014). The representation of exotic over native species when comparing cities from European and central Chile also extends to the habitats within the cities, particularly between squares and streets (see Lososová et al. 2012). In fact, in the analysed cities of Chile, there is a greater representation of exotic species than native ones in both streets and squares whereas native species dominate urban squares and streets in European cities (Lososová et al. 2012, 2016). Probably, these differences can be attributed to the use of a greater diversity of native species as ornamentals in European cities (Lososová et al. 2012, Kowarik et al. 2013), a fact that does not seem to be the case in central Chile (Figueroa et al. 2016, 2018).

On the other hand, and despite the efforts to promote a change (e.g. Riedemann \& Aldunate 2001, 2003, Riedemann et al. 2006, 2008) the scarce number of native species cultivated for ornamental programme purposes, could be related to the lack of knowledge around their possible use as ornamental plants, as well as to the misconception that Chilean native plants grow slowly. The only native species contrasting this general trend were Schinus areira, Quillaja saponaria, Maytenus boaria, Acacia caven and Cryptocarya alba whose incidence values were the highest among the natives and whose ornamental value, is well known. Given that some species such as Cryptocarya alba are considered vulnerable in the Metropolitan Region of the country (Benoit 1989, Riedemann \& Aldunate 2001), their use in urban settings could be a valuable mean for conservation. In Chile, the gymnosperms include various conifers among which there are native species of Araucariaceae, Cupressaceae, Podocarpaceae and Ephedraceae. In this study, we only found three species of gymnosperms reported for Chile: the native Araucaria araucana and the exotic Pinaceae Pinus radiata D. Don and Pseudotsuga menziesii (Mirb.) Franco. That means that the $94.1 \%$ of the Chilean gymnosperm flora (17 species), according to Marticorena \& Rodríguez (1995), would not be represented within the cities of this study. Similarly, this study showed that the representation of the angiosperms was not higher.

With regards to the origin of the ornamental exotic flora, the findings were not consistent with Matthei (1995), Arroyo et al. (2000), Figueroa et al. (2004), Castro et al. (2005), who report that most of the naturalised flora in Chile comes from Mediterranean Eurasia. On the other hand, LozanoDiéguez \& Teillier (2014) and Romero et al. (2009) found that $29 \%$ and $19 \%$ of the ornamental flora of the Chilean cities of Curicó and Temuco respectively, were of Asian origin. The prominent number of exotic species, especially from Asia, can be related with the large number of plants 
that European gardeners introduced first to Europe, and then to Chile in the nineteenth century, reflecting the English and French influence over the urban space's ornamentation style in Chile (Lozano-Diéguez \& Teillier 2014 and references therein).

Consistent with other studies, the analysis on species incidence has shown a general tendency to use many rare species and a few common species in streets and squares (Lososová et al. 2012, Kowarik et al. 2013). That is to say, only a minority of the species found were encountered in a consistent number of plots. Examples are Nerium oleander, Melia azedarach, Liquidambar styraciflua, Ligustrum lucidum, Ligustrum ovalifolium, Prunus cerasifera, Robinia pseudoacacia, and Acer negundo, all exotic to Chile. If making use of many rare species tends to increase diversity, the use of the same species in different cities decreases variability when comparing them.

It shows that exotic species strongly contribute to the homogenization of the floras of the cities studied (Aronson et al. 2014, La Sorte et al. 2014, Lososová et al. 2016). In fact, $90.2 \%$ of the species ( 37 out of 41 ) shared by all the five cities were exotic; however, the urban homogenization for Chilean cities needs further investigation. The other issue with the predominance of the exotic flora within the urban context, is that much of the species naturalised in Chile such as Rubus (Rosaceae), Rosa rubiginosa L. (Rosaceae), Acacia dealbata Link (Fabaceae) among the others, have turned out to be invasive and have replaced the native flora in many areas (Teillier 2008). Currently, we ignore if the urban populations of these species maintain reproductive relationships with the rural populations.

The use of native flora in cities could benefit in different ways. Not only it can provides support to the regional plant diversity; it can also create stepping stones or corridors for natural populations, as well as provide environmental education and ecosystem services (Dearborn \& Kark 2010). Theoretically, species that are well adapted to the local environmental conditions require less intervention for their maintenance (e.g. water requirements), which implicates the possibility of amortising the costs of maintenance. Another aspect, less obvious but realistically important for conservation, is the awareness of the public of native biodiversity. Some studies (Rozzi et al. 2003, Ballouard et al. 2011) have shown that when people are asked to recall species of their cities, they mostly named exotic ones and they are keener to prioritize virtual exotic iconic biodiversity over local biodiversity. Additionally, it has been pointed out that native plants species may be preferred by native birds, thus a higher representation of native flora it is expected to attract native avifauna to urban areas (Díaz \& Armesto 2003, White et al. 2005).

Conservation within urban landscapes could support regional and global biodiversity (Dearborn \& Kark 2010). Thus, a better monitoring of the urban biota in areas of high regional biodiversity is certainly needed (Aronson 2014). Our study shows that, at least in central Chile, the native flora is poorly represented and scarcely taken into consideration in urban planning ornamentation programmes. Cities are points of entry for numerous ornamental plants that could potentially naturalize, and spread their distribution toward extra-urban habitats, exerting an important impact upon the native biodiversity (Kowarik et al. 2013). The massive use of exotic flora in street and squares, especially from Asia, can be linked to historical as well as to socio-cultural drivers. Taking into consideration the importance of these drivers is fundamental to improve the sustainability of our cities and their relationship with the regional environment.

\section{ACKNOWLEDGEMENT}

This study was supported by DICYT 021543CM, USA1555.48, and the Center for the Development of Nanoscience and Nanotechnology (Line 6) of the Universidad de Santiago de Chile. JAF funded by intern project of the Universidad Central de Chile (CIP 16012).

\section{REFERENCES}

Altay, V., Ozyigit, I.I., Yarci, C. 2010. Urban flora and ecological characteristics of the Kartal District (Istanbul): A contribution to urban ecology in Turkey. Scientific Research and Essays 5: 183-200.

Aronson, M.F., La Sorte, F.A., Nilon, C.H., Katti, M., Goddard, M.A., LepczyK, C.A., DobBs, C. 2014. A global analysis of the impacts of urbanization on bird and plant diversity reveals key anthropogenic drivers. Proceedings of the Royal Society B 281: 20133330.

Arroyo, M.T.K., Marticorena, C., Matthei, O., Cavieres, L. 2000. Plant invasions in Chile: present patterns and future predictions. In: Mooney, H.A., Hobbs, R.J., Invasive species in a changing world, pp. 385-421. Washington, US: Island Press.

Ballouard, J.M., Brischoux, F., Bonnet, X. 2011. Children prioritize virtual exotic biodiversity over local biodiversity. PloS ONE 6: e23152.

Benoit, I. 1989. Libro rojo de la flora terrestre de Chile (Primera parte). Corporación Nacional Forestal. Santiago. 158 pp.

Carretero, E.E.M. 2010. The synanthropic flora in the Mendoza (Argentina) urban area. Urban Ecosystems 13: 237-242.

Castro, S.A., Figueroa, J.A., Muñoz-Schick, M., Jaksic, F.M. 2005. Minimum residence time, biogeographical origin, and life cycle as determinants of the geographical extent of naturalized plants in continental Chile. Diversity and Distributions 11: 183-191.

Celesti-Grapow, L., Capotorti, G., Del Vico, E., Lattanzia, E., Tilia, A., Blasia, C. 2013. The vascular flora of Rome. Plant Biosystems 147: 1059-1087.

Córdova-Stroobandt, K.L. 2013. Caracterización de la biodiversidad urbana en la cuenca central de Cochabamba, Bolivia. Acta Nova 6: 94-121. 
Dearborn, D.C., Kark, S. 2010. Motivations for conserving urban biodiversity. Conservation biology 24: 432-440.

Díaz, I.A., Armesto, J.J. 2003. La conservación de las aves silvestres en ambientes urbanos de Santiago. Ambiente y Desarrollo 19: 31-38.

Environmental Systems Research Institute (ESRI). 2012. ArcGIS Release 10.1. Redlands, California.

FAETH, S.H., BANG, C., SAARI, S. 2011. Urban biodiversity: patterns and mechanisms. Annals of the New York Academy of Sciences 1223: 69-81.

Figueroa, J.A., Castro, S.A., Jaksic, F.M., Marquet, PA. 2004. Exotic plants invasions to the Mediterranean region of Chile: causes, history and impacts. Revista Chilena de Historia Natural (Chile) 77: 465-483.

Figueroa, J.A., Castro, S.A., Marquet, P. A., Jaksic, F. M. 2004. Exotic plant invasions to the mediterranean region of Chile: causes, history and impacts. Revista Chilena de Historia Natural 77: 465-483.

Figueroa, J.A., Castro, S.A., Reyes, M., Teillier, S. 2018. Urban park area and age determinate the richness of native and exotic plants in parks of a Latin American city. Urban Ecosystems 21:645-655.

Figueroa, J.A., Teillier, S., Guerrero-Leiva, N., Ray-Bobadilla, C., Rivano, S., SaAvedra, D., Castro, S.A. 2011. Diversity patterns and composition of native and exotic floras in central Chile. Acta Oecologica 37: 103-109.

Figueroa, J.A., Teillier, S., Castro, S.A. 2016. Vascular flora in public space of Santiago, Chile. Gayana Botánica 73: 85103.

Fischer, L.K., Rodorff, V., Von der Lippe, M., KowariK, I. 2016. Drivers of biodiversity patterns in parks of a growing South American megacity. Urban Ecosystems 19: 12311249.

Fuentes, E.R., Avilés, R., Segura, A. 1989. Landscape change under indirect effects of human use: the Savanna of Central Chile. Landscape Ecology 2: 73-80.

Fuentes, N., Pauchard, A., Sánchez, P., Marticorena, A. 2013. Alien plants in Chile: inferring invasion periods from herbarium records. Biological Invasions 10: 649-657.

Fuentes, N., Ugarte, E., Kühn, I., Klotz, S. 2008. Alien plants in Chile: inferring invasion periods from herbarium records. Biological Invasions 10: 649-657.

Gärtner, E., Rojas, G., CAstro, S.A. 2015. Compositional patterns of ruderal herbs in Santiago, Chile. Gayana Botánica 72: 192-202.

Godefroid, S., Koedam, N. 2007. Urban plant species patterns are highly driven by density and function of built-up areas. Landscape Ecology 22: 1227-1239.

Grapow, L.C., Blasi, C., Andreis, C., Biondi, E., Raimondo, F.M., Mossa, L. 1996. Studio comparativo sulla flora urbana in Italia. Plant Biosystem 130: 779-793.

Grapow, L.C., PYšEk, P., Jarošík, V., Blasi, C. 2006. Determinants of native and alien species richness in the urban flora of Rome. Diversity and Distributions 12: 490-501.

Grimm, N.B., Faeth, S.H., Golubiewski, N.E., Redman, C.L., Wu, J., BAI, X., Briggs, J.M. 2008. Global change and the ecology of cities. Science 319: 756-760.

Hernández, H.J., Villaseñor, N.R. 2018. Twelve-year change in tree diversity and spatial segregation in the Mediterranean city of Santiago, Chile. Urban Forestry and Urban
Greening 28: 10-18.

Hoffmann, A.J. 1998. El árbol urbano en Chile. Fundación Claudio Gay, Santiago, Chile. 79 pp.

Hollis, S., Brummitt, R.K. 2001. World Geographical Scheme for Recording Plant Distributions. Hunt Institute for Botanical Documentation, Carnegie Mellon University, Pittsburgh. $137 \mathrm{pp}$.

INE 2005. Chile: Ciudades, Pueblos, Aldeas y Caseríos. URL: http://www.ine.cl Accessed: August, 2017.

Kent, M., Stevens, R. A., Zhang, L. 1999. Urban plant ecology patterns and processes: a case study of the flora of the City of Plymouth, Devon, UK. Journal of Biogeography 26: 1281-1298.

Kowarik, I., Von der Lippe, M., Cierjacks, A. 2013. Prevalence of alien versus native species of woody plants in Berlin differs between habitats and at different scales. Preslia 85: 113-132.

La Sorte, F.A., Aronson, M.F., Williams, N.S., Celesti-Grapow, L., Cilliers, S., Clarkson, B.D., Pyšek, P. 2014. Beta diversity of urban floras among European and nonEuropean cities. Global Ecology and Biogeography 23: 769-779.

Leporatti, M.L., Pavesi, A., Massari, G. 2001. Contributo alla conoscenza della flora vascolare urbana di Chieti (Abruzzo). Webbia 56: 343-378.

LososovÁ, Z., Chytry, M., Danihelka, J., Tichy, L., Ricotta, C. 2016. Biotic homogenization of urban floras by alien species: the role of species turnover and richness differences. Journal of Vegetation Science 27: 452-459.

Lososová, Z., Chytrý, M., TichÝ, L., Danihelka, J., Fajmon, K., Hájek, O., Kintrová, K., Kühn, I., LÁníKovÁ, D., OtÝPKOVÁ, Z., ŘEHOŘEK, V. 2012. Native and alien floras in urban habitats: a comparison across 32 cities of central Europe. Global Ecology and Biogeography 21: 545-555.

Lozano-Diéguez, A.M.L., Teillier, S. 2014. Frecuencia y abundancia de especies leñosas utilizadas en espacios públicos de la ciudad de Curicó-Región del MauleChile. Chloris Chilensis Año 17, $\mathrm{N}^{\circ}$ 2. URL: http://www. chlorischile.cl.

Luebert, F., Pliscoff, P. 2006. Sinopsis bioclimática y vegetacional de Chile. Editorial Universitaria, Santiago, Chile. 384 pp.

Marticorena, C. 1990. Contribución a la estadística de la flora vascular de Chile. Gayana Botánica 47: 85-113.

Marticorena, C., Quezada, M. 1985. Catálogo de la flora vascular de Chile. Gayana Botánica 42: 5-157.

Marticorena, C., Rodríguez, R. 1995. Flora de Chile. Vol 1. Ediciones Universidad de Concepción, Concepción, Chile. $531 \mathrm{pp}$.

Matthei, O. 1995. Manual de las Malezas que Crecen en Chile. Alfabeta Impresores, Santiago. 545 pp.

Maurer, U., Peschel, T., Schmitz, S. 2000. The flora of selected urban land-use types in Berlin and Potsdam with regard to nature conservation in cities. Landscape and Urban Planning 46: 209-215.

McKinneY, M.L. 2006. Urbanization as a major cause of biotic homogenization. Biological Conservation 127: 247-260.

McKinney, M.L., Lockwood, J.L. 1999. Biotic homogenization: a few winners replacing many losers in the next mass extinction. Trends in Ecology \& Evolution 14: 450-453.

MÉndEZ, E. 2005. Flora y vegetación del centro urbano de Luján 
de Cuyo. Mendoza (Argentina). Revista de la Facultad de Ciencias Agrarias 37: 67-74.

Milovic, M., Mitic, B. 2012. The urban flora of the city of Zadar (Dalmatia, Croatia). Natura Croatica 21: 65-100.

Moro, M.F., Castro, A.S.F. 2015. A check list of plant species in the urban forestry of Fortaleza, Brazil: where are the native species in the country of megadiversity? Urban Ecosystems 18: 47-71.

ONU. 2014. World Urbanization Prospects: The 2014 Revision, Highlights. Department of Economic and Social Affairs. Population Division, United Nations. 28 pp.

Pauchard, A., Aguayo, M. , Peña, E., Urrutia, R. 2006. Multiple effects of urbanization on the biodiversity of developing countries: the case of a fast-growing metropolitan area (Concepción, Chile). Biological Conservation 127: 272281.

Pauchard, A., Cavieres, L., Bustamante, R. 2004. Comparing alien plant invasions among regions with similar climates: where to from here? Diversity \& Distributions 10: 371375.

Ray, C.A., Escobedo-Echeverría V., Castro, S.A., Jaksic, F.M. 2014. Catálogo de la flora y fauna invasora. En: Invasiones Biológicas: causas globales e impactos locales. Ediciones UC 491-509.

Richardson, D.M., Pyšek, P., Rejmanek, M., Barbour, M.G., PanetTA, F.D., West, C.J. 2000. Naturalization and invasion of alien plants: concepts and definitions. Diversity and Distributions 6: 93-107.

Ricotta, C., Godefroid, S., Rocchini, D. 2010. Patterns of native and exotic species richness in the urban flora of Brussels: rejecting the 'rich get richer' model. Biological Invasions 12: 233-240.

Riedemann, P., Aldunate, G. 2001. Flora Nativa de Valor Ornamental de Chile, Zona Centro. Editorial Andrés Bello, Chile. 566 pp.

Riedemann, P., Aldunate, G. 2003. Flora Nativa de Valor Ornamental de Chile, Zona Sur. Editorial Andrés Bello, Chile. 516 pp.

Riedemann, P., Aldunate, G., Teillier, S. 2008. Flora nativa de valor ornamental de Chile: Zona Cordillera de los Andes. Ediciones Jardín Botánico Chagual, Chile. 674 pp.
Riedemann, P., Aldunate, G., Teillier, S. 2006. Flora Nativa de Valor Ornamental: Zona Norte. Ediciones Jardín Botánico Chagual, Chile. 404 pp.

Rodríguez, R.R., Matthei, S.O., Quezada, M.M. 1983. Flora Arbórea de Chile. Editorial de la Universidad de Concepción, Chile. 408 pp.

Rodríguez, R.R., Ruiz, E., Elissetche. J.P. 2005. Árboles en Chile. Editorial Universidad de Concepción, Chile. 183 pp.

Romero-Mieres, M., Rebolledo, S., Jaramillo, P. 2009. Árboles ornamentales de la ciudad de Temuco, Región de la Araucanía (IX), Chile. Chloris Chilensis, Año 12, $\mathrm{N}^{\circ} 1$. URL: http://www.chlorischile.cl.

Rozzi, R., Silander, J., Dollenz, O., Massardo, F., Anderson, C., Connolly, B. 2003. Árboles nativos y exóticos en las plazas de Magallanes. Anales del Instituto de la Patagonia, Serie Ciencias Naturales 31: 27-42.

SAX, D.F., Gaines, S.D. 2003. Species diversity: from global decreases to local increases. Trends in Ecology \& Evolution 18: 561-566.

SteŠEvić, D., Caković, D., Jovanović, S. 2014. The urban flora of Podgorica (Montenegro, SE Europe): annotated checklist, distribution atlas, habitats and life-forms, taxonomic, phytogeographical and ecological analysis. Ecologica Montenegrina 1: 1-171.

TeILlier, S. 2008. Flora vascular. En: Comisión Nacional del Medio Ambiente (eds.). Biodiversidad de Chile, Patrimonio y Desafíos. Ocho libros, Santiago, Chile. 310-339.

The Plant List. 2013. Version 1.1. URL: http://www.theplantlist. org. Accessed: 2017.

Van der Veken, S., Verheyen, K., Hermy, M. 2004. Plant species loss in an urban area (Turnhout, Belgium) from 1880 to 1999 and its environmental determinants. FloraMorphology, Distribution, Functional Ecology of Plants 199: 516-523.

White, J.G., Antos, M.J., Fitzsimons, J.A., Palmer, G.C. 2005. Non-uniform bird assemblages in urban environments: the influence of streetscape vegetation. Landscape and Urban Planning 71: 123-135.

Zuloaga, F., Morrone, O., Belgrano, M. 2009. Catálogo de las plantas vasculares del Cono Sur Versión base de datos en sitio web del Instituto Darwinion, Argentina. URL: http:// www.darwin.edu.ar/Proyectos/FloraArgentina. Accessed: 2015. 


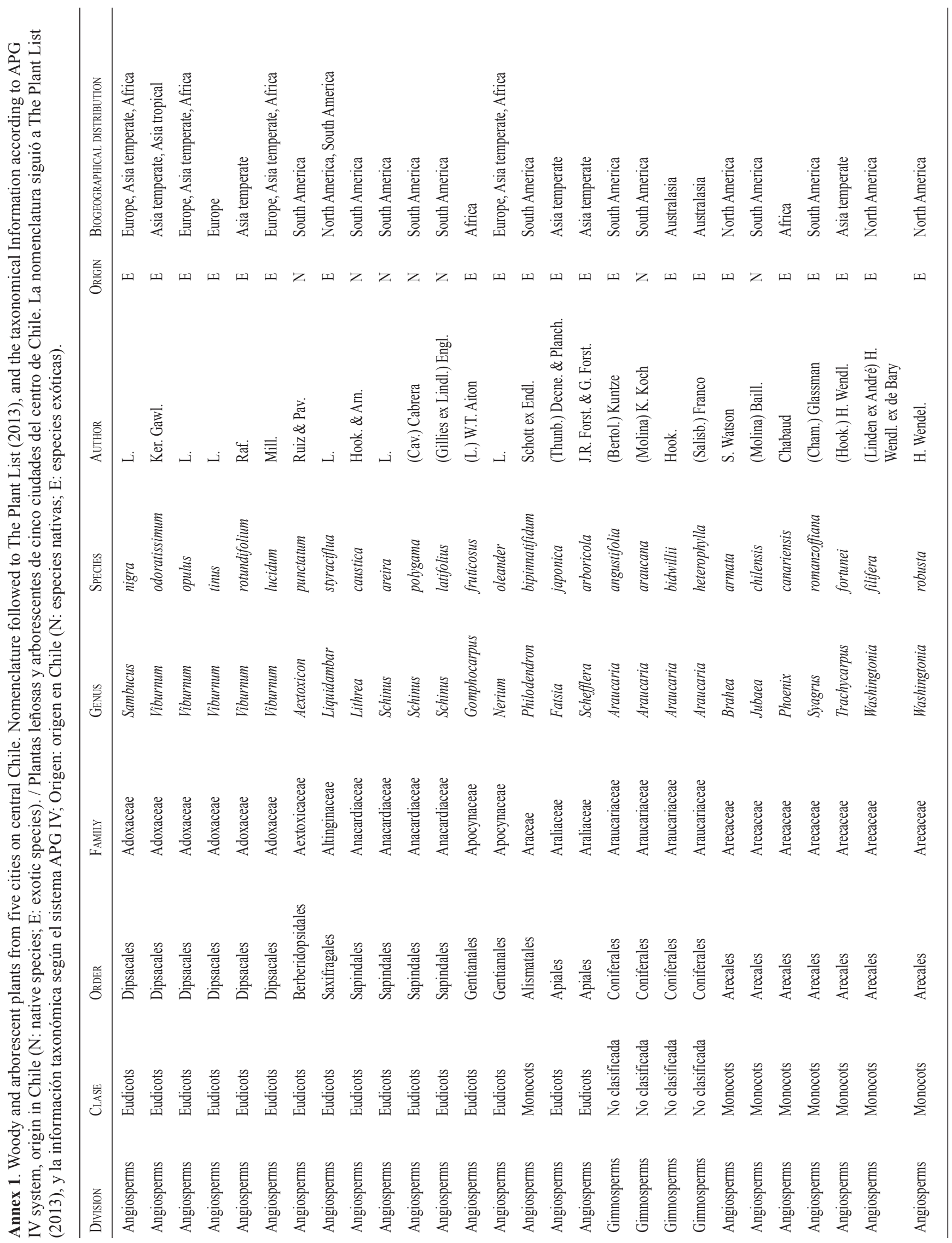




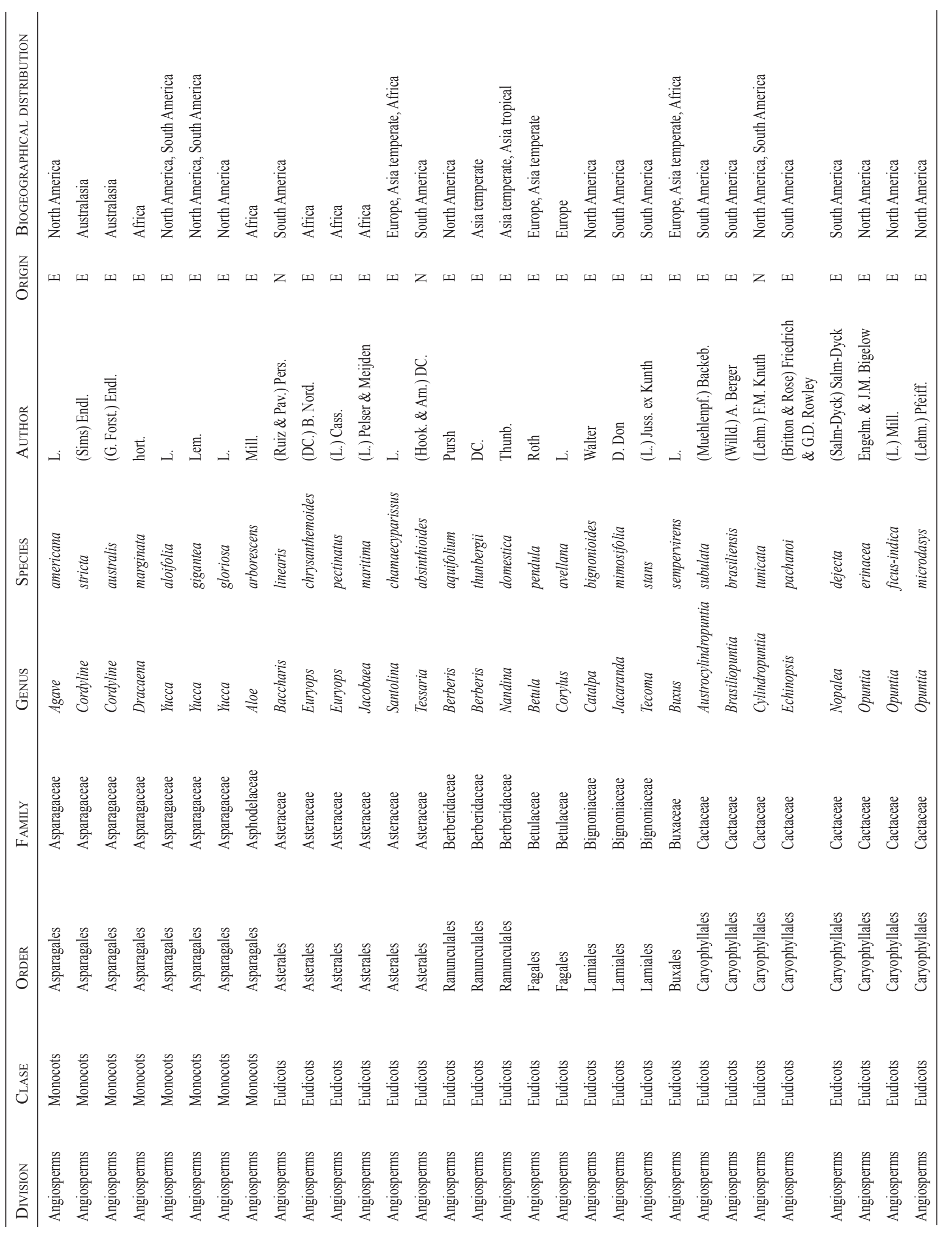




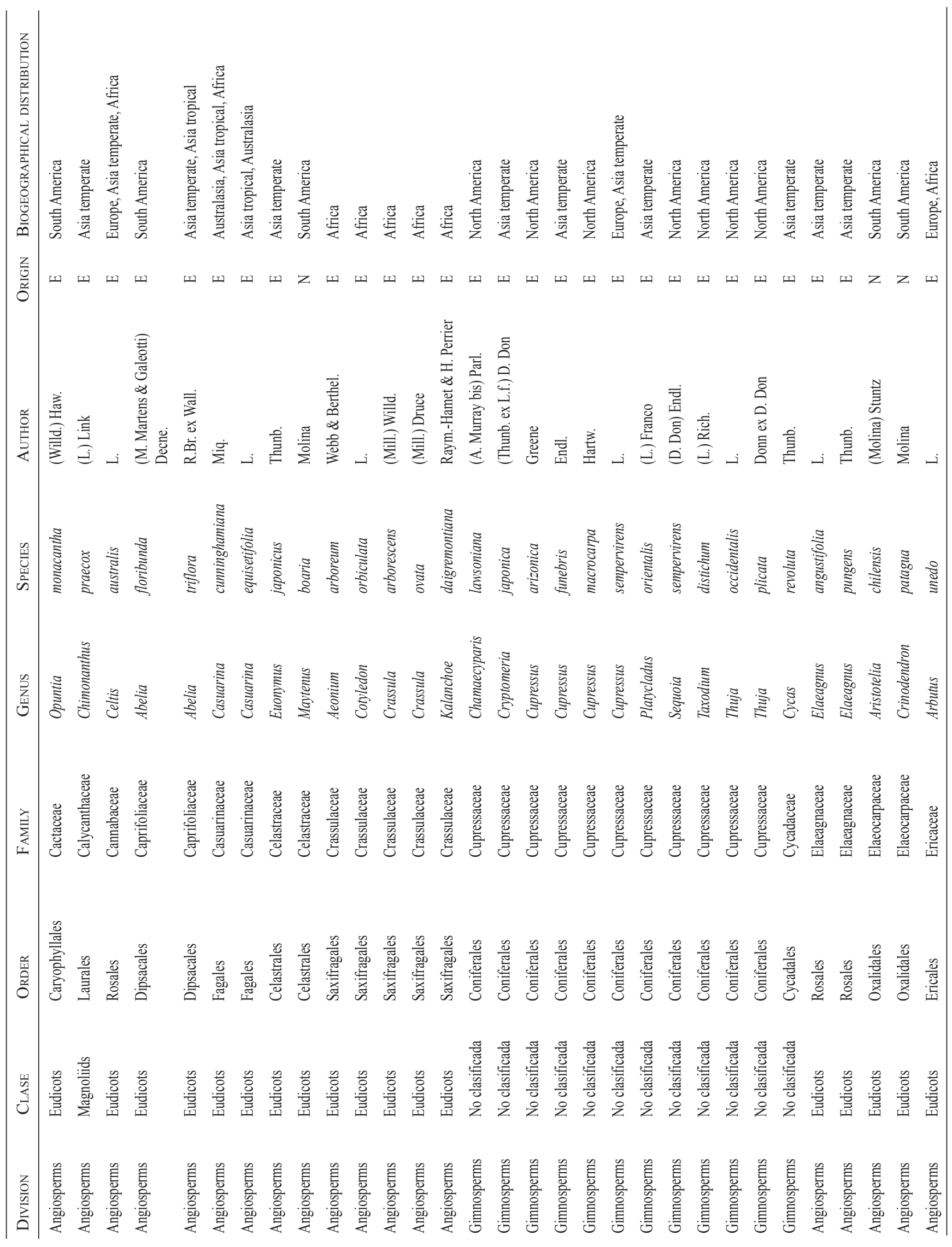




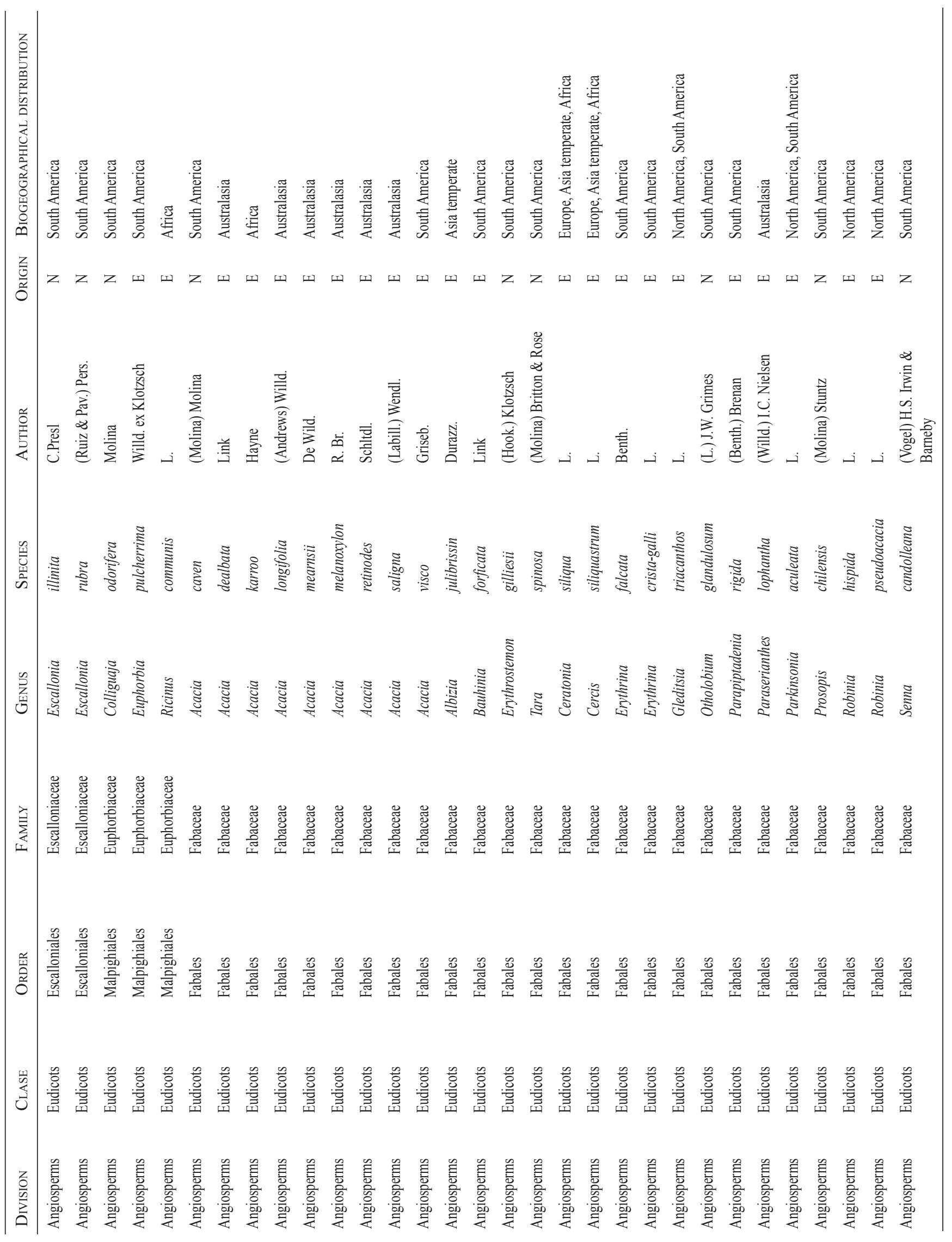




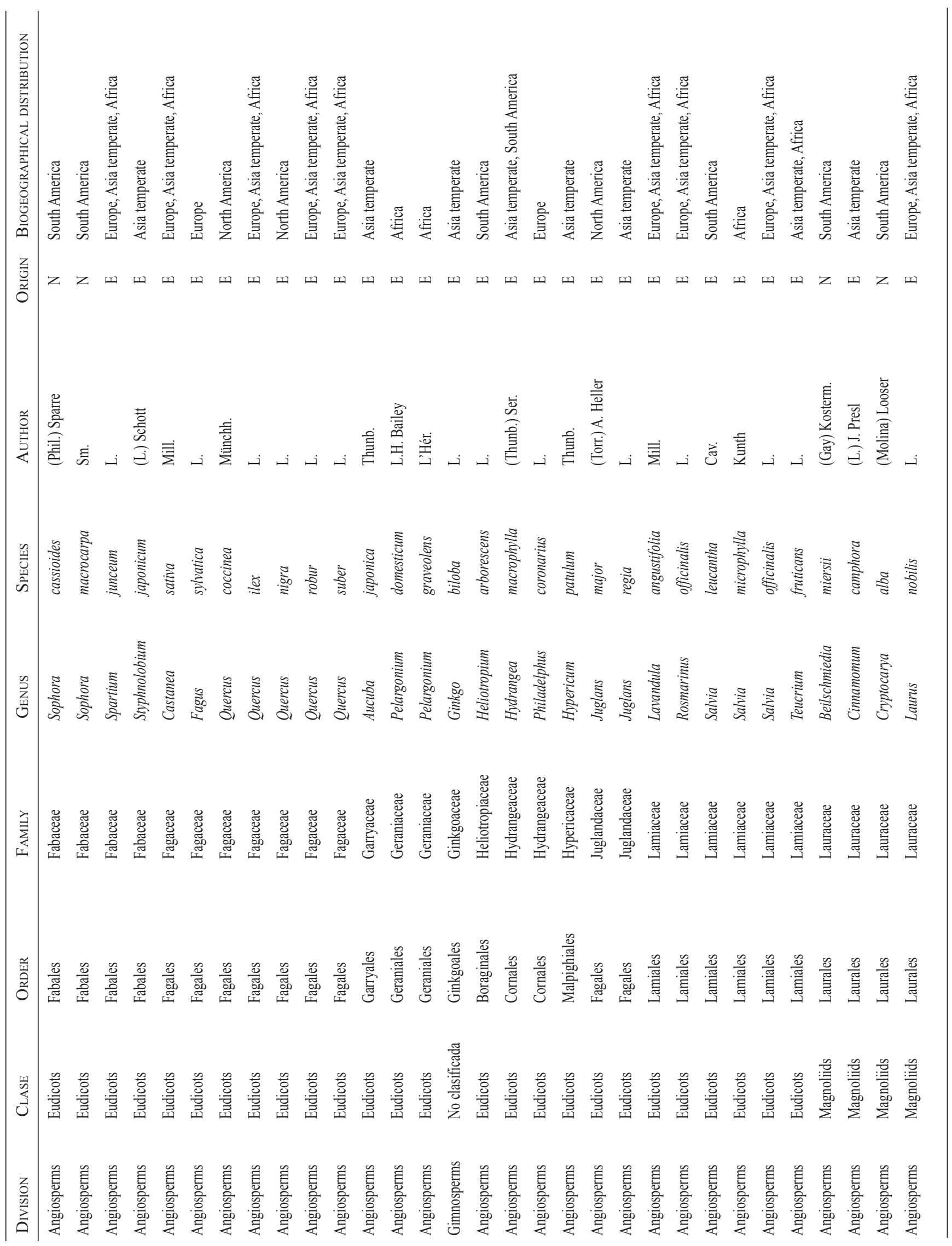




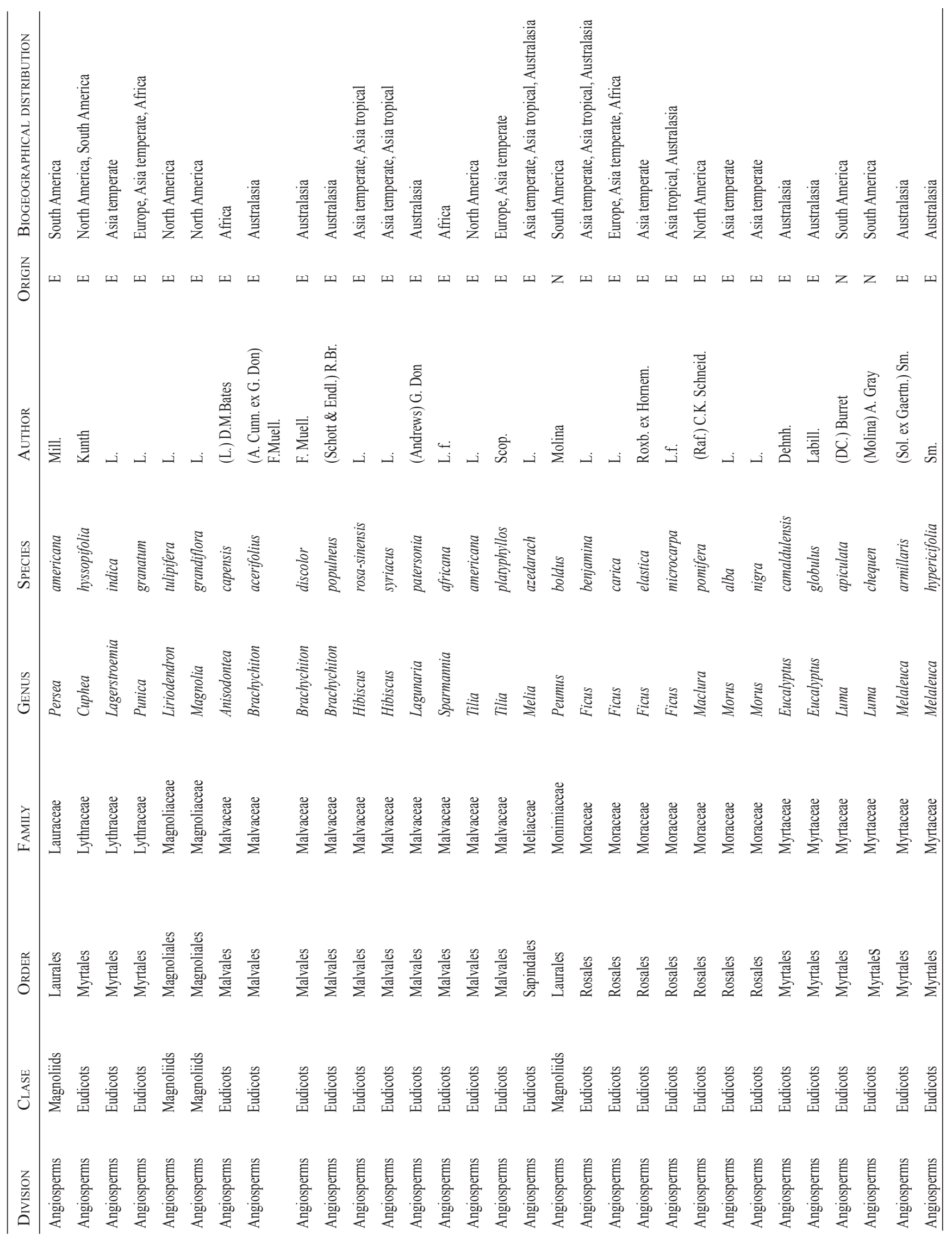




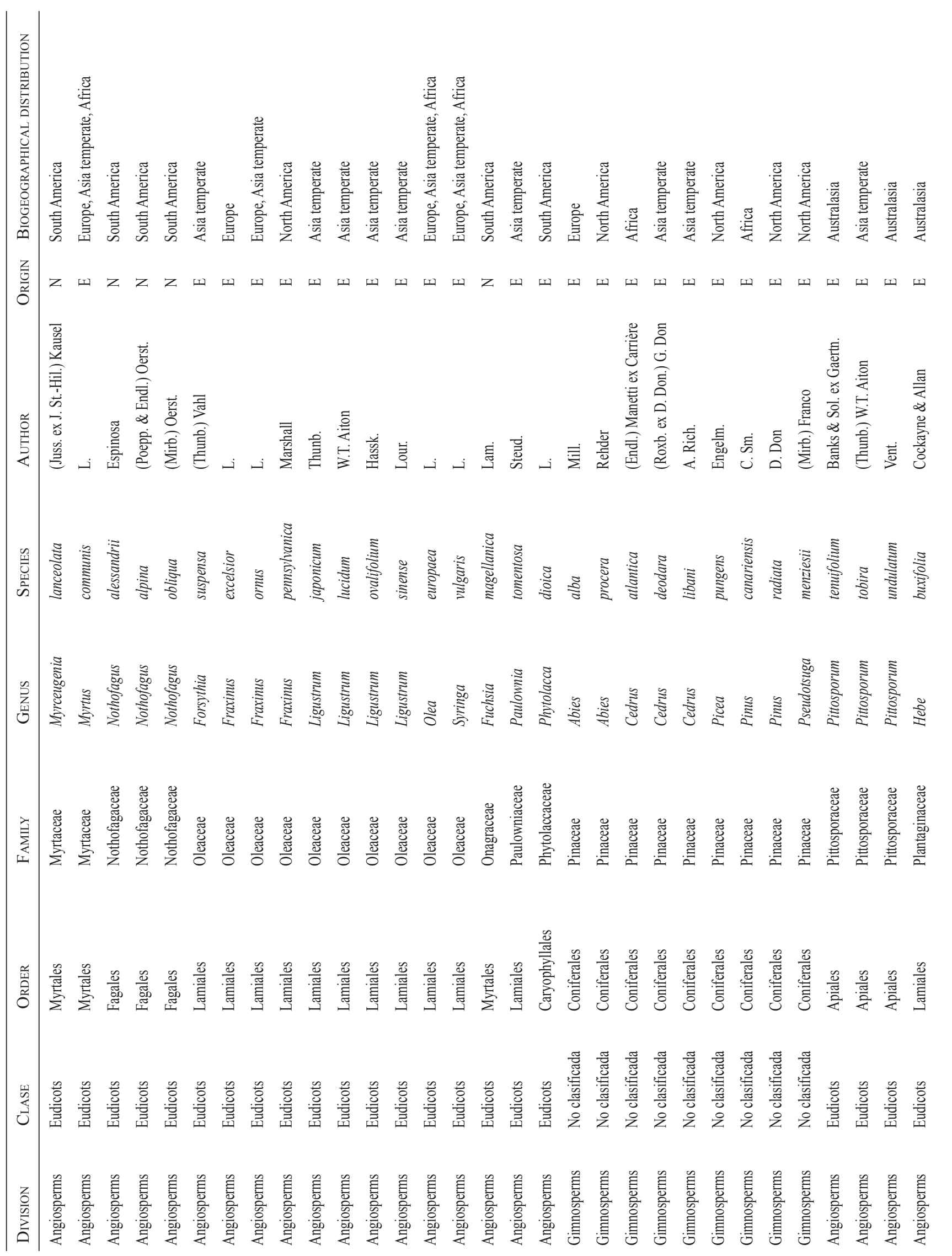




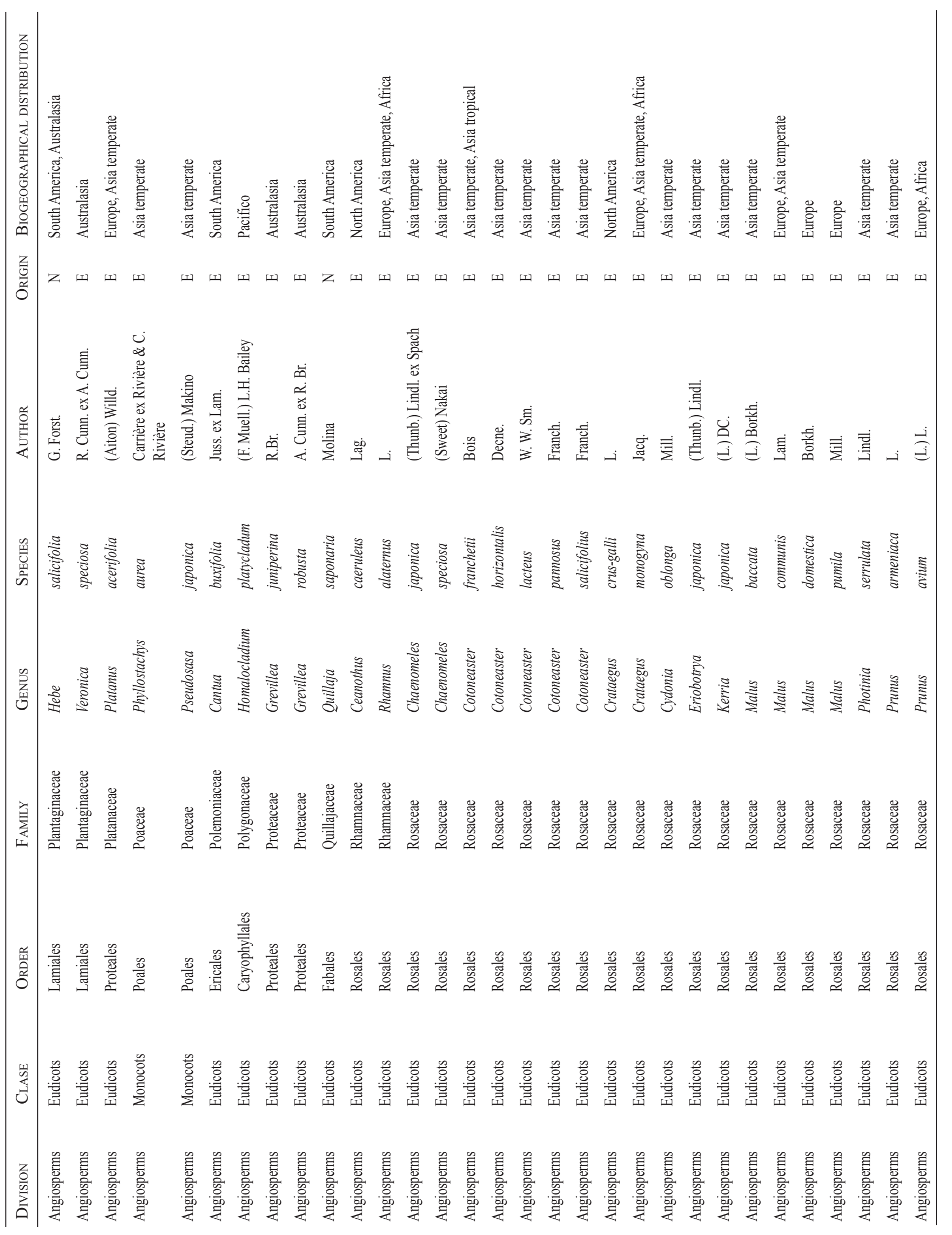




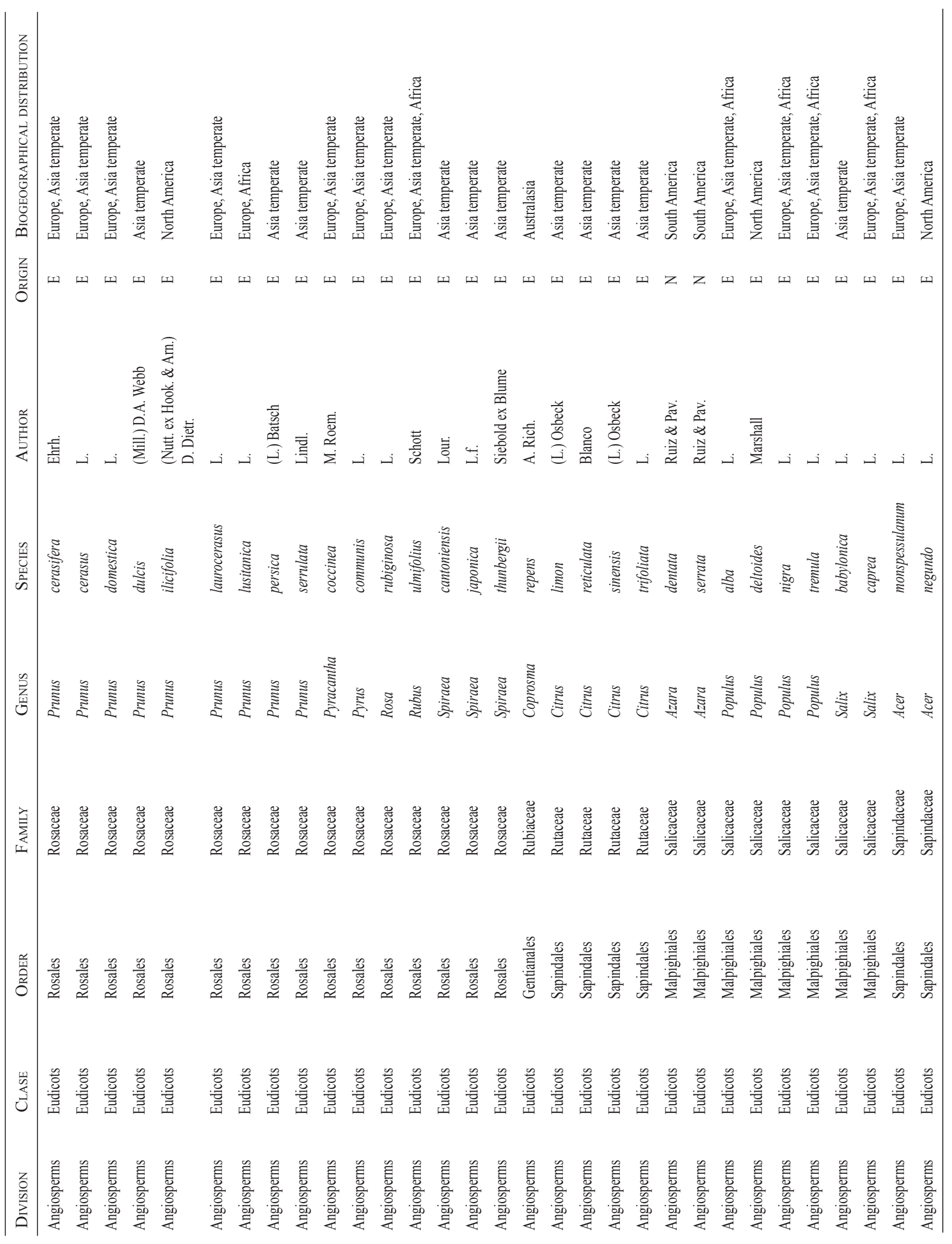




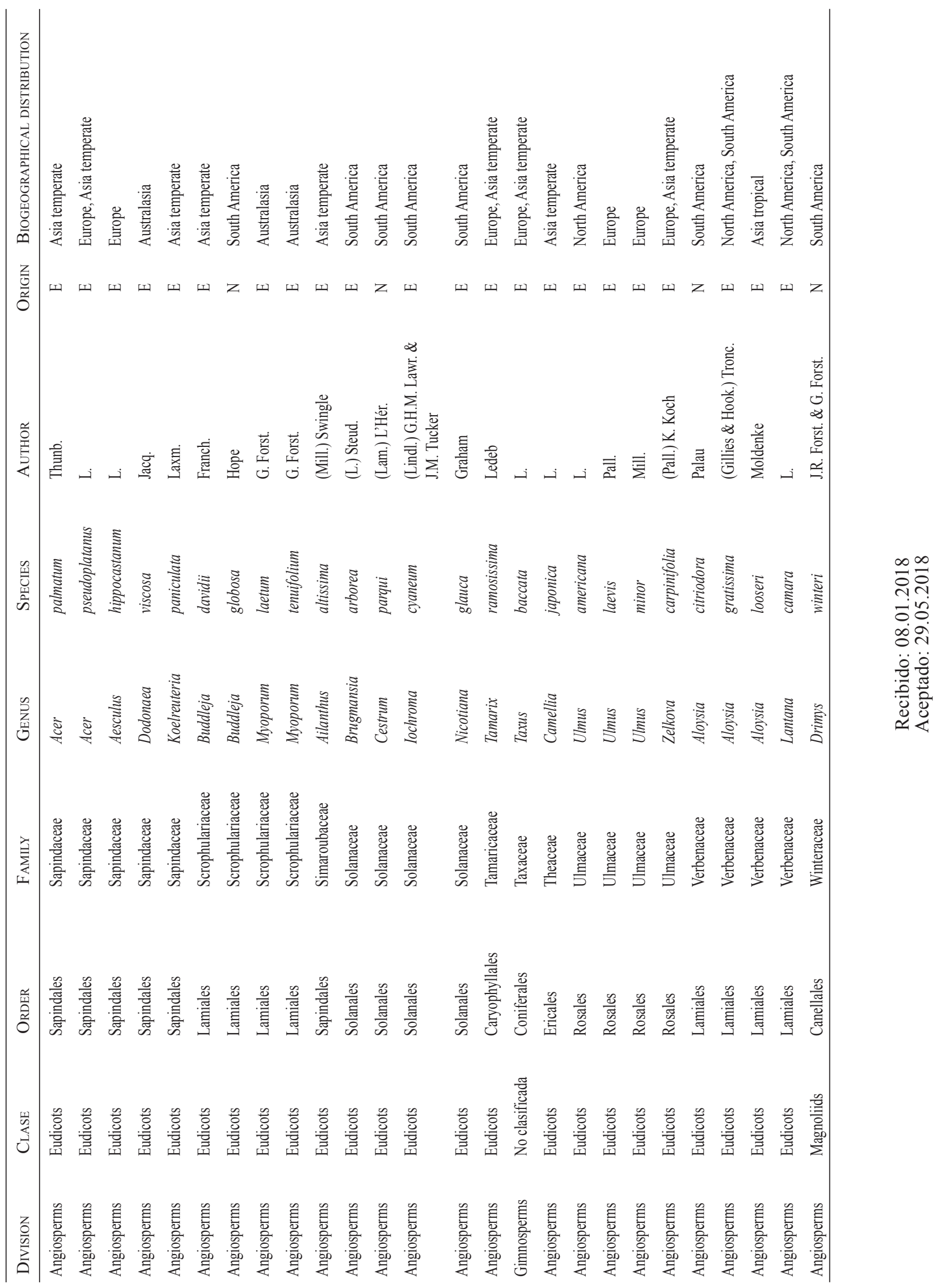

